\title{
The Purposes of Graduate Education: An Historical Perspective
}

\author{
M. A. Preston *
}

The Beginning of the Future, a Historical Approach to Graduate Education in the Arts and Sciences, by Richard J. Storr. Sponsored by The Carnegie Commission on Higher Education. McGraw-Hill Book Co., 1973, pp. xviii +99.

Professor Storr refers to his book as an "essay," perhaps to emphasize the personal quality which imbues it. It is not primarily a history - Professor Storr's earlier work The Beginnings of Graduate Education in America has already given us that. Rather, as the subtitle indicates, it is an historically informed approach to a discussion of some of the central issues of graduate study which confront us today. Professor Storr believes that the academic community should be examining the bases of its activity in advanced study, since to an appreciable extent its development will be determined by its attitudes to these questions. Standards must be subjected to a systematic and continuing audit... "What matters primarily is not that offices of institutional research be set up, that committees be appointed to write self-study reports, or that some professors turn to examination of academic life as their specialized field, although each of these is a step forward. The stake is deeply informed understanding of the university, across the university, not least among graduate students. Those enrolled today will not retire from active life, many of them as academics, until the year 2000 is a memory. What we all think of the university, past and present, is the beginning of the future."

Those are the concluding words of the book. Before them we are treated to an historical account in fifty to sixty pages of the development of graduate education in the United States, followed by an analysis of the meaning of graduate education and its

* Executive Vice-Chairman, Advisory Committee on Academic Planning, Ontario Council on Graduate Studies ; Professor of Physics and of Applied Mathematics, McMaster University. 
purposes. The historical part emphasizes the philosophical approaches - and the debates about them - which led to the appearance of "universities" where formerly there had been only "colleges," the language of that day when some spoke of establishing the American university, characterized by its central attention to inquiry as well as teaching.

The second part of the book deals with current perceptions of the unresolved problems still with us from those times. The perennial nature of these problems may be illustrated by four quotations from the book. In 1905 Dean West of Princeton wrote :

The impulse to produce, produce, produce - a splendid thing when a man cannot help doing a great thing - is an awful thing when second-and third-rate men are being told to produce what they can produce - that is, merely second and third-rate stuff.

In 1973, Professor Storr writes :

The adjective original was less a qualifier of research than an epithet - it is difficult to imagine the ceremony where diplomas are conferred for unoriginal research. If it is true, however, that much work for which degrees are awarded is actually of just that kind, is it the better part of realism to surrender the idea that graduate degrees should stand for originality?

In 1912, Dean Woodbridge of Columbia wrote :

They [Ph.D.'s] graduate, not as accomplished scholars, but as students who by their research have demonstrated their capacity. We are confident of them and hopeful, ready to commend them staunchly. They are, however, prisoners of hope, not sons of Greece.

and in 1973 Professor Storr speaks as follows of the distinction between degrees which certify technical preparedness for inquiry and those which recognize a significant contribution :

It is rational to grant both kinds of degrees, provided the distinction is observed; and it is honest to grant but a single degree, standing for technical preparedness, and to leave it to the transcript or a letter of appraisal to show that a particular student has exceeded the requirements; but it is neither rational nor honest to grant but a single degree, standing for achievement in the advancement of inquiry, unless the graduate school is ready to flunk candidates of whom no more can be said at the end than that they are well trained.

In the first 60 or 70 pages of the book, where the impact of Professor Storr's personal view point is not so evident, the various sides of the problems are clearly exposed in a very readable and entertaining way. It is salutary to be reminded that we have been facing some central problems for more than a century, that various steps have been taken to resolve them based on various philosophies and that none have been uniformly 
successful: Indeed, as Professor Storr suggests, just at the time in the 1960's when many academics felt that the development of the graduate schools was bringing to reality the dream of their predecessors, others feit that the dream had become a nightmare.

The constituents of the nightmare are the current arguments about research vs. breath and knowledge, education vs. training, free inquiry vs. relevance, graduate degrees as union tickets, graduate degrees as social cachets, mastery of a discipline vs. interdisciplinary problem solving. We may note in passing that the book does not deal with one of the dichotomies - national vs. international scholarship - which is a current component of the Canadian brand of the nightmare. Of course, scholastic atavism is not unique to modern Canada, but it does not engage Professor Storr's attention.

In the last portion of the book, Professor Storr gives his viewpoint on many. of these debates, in the form of a defense of five propositions :

1. Graduate education is essentially a vehicle of inquiry, which leads the mind out, and as such, graduate education is to be thought of primarily as being indeed education rather than training.

2. As a governing force in graduate education, the possibilities of inquiry at any given moment should have a higher claim than existing professional demands.

3. The graduate school should foster the advancement of inquiry both intensively and extensively.

4. Programs of study should be defined primarily by arriving at the closest match possible between the intellectual bent of the individual student and the whereabouts of the knowledge to which clusters of professors are drawn by their questioning.

5. Graduate study should carry the student with the least avoidable delay to attack the questions that are most worth answering.

There is a more catholic view of the nature of graduate work which is epitomized by a saying attributed to Dean Elder of Harvard. Contemplating the variety of masters' degrees, he was moved to note that a master's degree is like a whore, all things to all men but at varying prices. With more words and dignity, but with little more content, the McMaster University graduate calendar contains a statement (written by a committee) which also displays the wide range of approaches to graduate study:

The aims of graduate work may be described as the highest development of the powers of reasoning, judgment and evaluation in intellectual concerns; as specialized training in professional skills; as initiation into research or scholarly work and development of a capacity for its successful and independent pursuit ; as the fruitful pursuit of research and scholarly work. 
Professor Storr's five principles seem to leave no doubt about which he considers the most important amongst these numerous, and perhaps conflicting, aims. And yet his position is not without modifiers. His first principle identifies "inquiry" as the main concern, but he says that "any degree in the control of the graduate school should imply that the recipient is well trained to engage in some kind of inquiry." He makes clear that the second principle is not to exclude professional programs from the graduate school, but rather to stress the "idea of education (which) should determine the priorities by which the work of each and every student in the school is governed." The third principle is not to exclude any methodologies but to embrace both "research" degrees and "synthesis" degrees. The text following the fourth principle makes clear that it does not attack the traditional disciples as "custodians of standards" but rather calls for an "ecumenical" treatment of some students. The fifth principle is indeed an ideal, but in practice how one brings a student to attack important questions with the least avoidable delay depends very much on what equipment one feels he should have in order to attack important questions. How broad a knowledge of his discipline(s) is needed ? Does he need a time for "ideas to lie fallow" ? How many preliminary exercises in research technique are required? How fundamental a question should a doctoral student be encouraged to examine?

In short, Professor Storr, like all wise men, realized that there is no position amongst all these choices which is simultaneously simple and defensible. Rather one is better advised to have in mind some ideals which one expects graduate schools to emphasize in greater or lesser degree in specific programmes, weighing other reasonable aims against the ideals but never abandoning them.

Whether or not, in this historical debate, one is inclined to adopt a position near that of Professor Storr or one somewhere else in the spectrum of philosophies of graduate education, one can not fail to profit from the sequence of thought laid out with such clarity and conciseness in this book. 